UDC 541. 183.02:678. 5:547.333.22-126

\title{
Adsorption Phenomena of Polyethyleneimine onot $\alpha$-Cellulose in Binary Solvent System. (Part II)
}

\author{
Katsuo Akagane* and Graham Allan** \\ Kansai Paint Co.
}

\begin{abstract}
Adsorption phenomena of polyethyleneimine onto cellulose in water-organic solvent system was investigated. As a result, minimum adsorption was observed in case of $1: 1$ volume ratio of binary system, while maximum adsorption was in water or organic solvent alone.

It has been demonstrated in the series of this study that both in ethyl alcohol and methyl alcohol the higher retention was observed in comparison with aqueous system but the lowest in the binary system.

The adsorption step was decisive to the PEI retention, but the wash condition did not show much influence on the PEI retention. From the result of swelling value of cellulose, it was recognized that the retention of polymer did not have direct correlation to swelling. The measurement of viscocity, however, showed the strong correlation to the retention. Therefore, from these results, it was pointed out that the adsorption phenomena of polyelectrolyte to porous material like cellulosic fiber in water-organic solvent system also could be well interpreted by using so called "Jack in the box effect". (1,2)
\end{abstract}

* 5-27 Chome, Fushimi-cho, Higashi-ku, Osaka, Japan.

** College of Forest Resources and Department of Chemical Engineering, University of Washington, Seattle, Washington 98105. 


\title{
二成分溶媒系におけるポリエチレンイミン のセルロースに対する収着現象（その II）
}

\author{
赤金華津 男*.Graham ALLAN**
}

\begin{abstract}
要
旨

ポリエチレンイミンの水-有機溶媒混合系に怙ける $\alpha$-セルロースに対する収着について 検討した。その結果, 水一有機溶媒の容積混合比が同等の場合に最小の収着量を示し, 一 方, 水または有機溶媒単独の場合には高い収着量を示した。検討した有機溶媒の範囲内で, アルコール系中では, ともに水溶媒中よりる高い収着量を示し, 混合系では最小収着量を 示した。アセトン, テトラヒドロフラン中では収着量はいずれも水溶媒中に和けるよりも 少ない值であったが，混合系炕特いてはエチルアルコールにみられたような極端な収着量 の低下は認められなかった。次に，洗浄時における二成分系溶媒の収着に及汸す影響を調 べた結果, 収着量は収着時の溶媒組成により支配され, 洗浄時の溶媒組成はほとんぞ影響 を及注さないことが認められた。セルロースの膨潤率の検討の結果，この収着現象と直接 的な関係は得られなかった。一方, 粘度測定の結果, この収着現象と強く関係しているこ とがわかった。これらから水一有機溶媒混合系に特ける収着現象もビックリ箱効果 ${ }^{1,2}$ を用 いて説明できることが判明した。
\end{abstract}

\section{1. 緒言}

二成分系有機溶媒中に特けるメチルメタアクリレート 和よびポリエチレングリコールのセルロースに対する収 着の研究は Robertson ら ${ }^{3,4}$ により報告されている。し かし, その多くの研究は有機溶媒どらしの混合系であ り, ポリエチレンイミンのような高分子電解質の水一有 機溶媒混合系に掠けるセルロース繊維に対する収着現象 の研究はまだ例をみない。

本研究は高分子電解質の水一有機溶媒混合系に打ける セルロースに対する収着現象を検討するため高分子電解 質としてポリエチレンイミン（以下 PEI と省略する）を 使用し, エチルアルコール・メチルアルコール・アセト ン特よびテトラヒドロフランの有機溶媒と水混合系に拉 ける収着量を窒素分析により決定した。また，水一有機 溶媒混合系に和ける混合比の収着量, 膨潤率和よび固有 粘度に及ぼす影響について検討した。

昭和 46.3 .22 受理

* 関西ペイント株式会社

大阪市東区伏見町 5-27

** Univ. of Washington, Seattle Washington 98105
2. 実

験

\section{1 収着量}

セルロース試料として ITT-Rayoner 社提供の精製ク ラフトパルプを使用した。試料 $5 \mathrm{~g}$ をあらかじめ容積混 合比でつくられた混合溶液 $250 \mathrm{~m} l$ に浸セキし，機械 的かきまぜ $(100 \mathrm{rpm}$ ) のもとに PEI (分子量 1,200 , Dow Chemical 社提供第一級アミン $25 \%$, 第二級アミ ン $50 \%$ ，第三級アミン $25 \%$ ）を試料あたり $0.145 \mathrm{~g}$ (約 $1 \%$ 窒素含有量/グラムセルロース試料) を加えた。温 度 $20^{\circ} \mathrm{C}$ のもとに和いて 2 時間浸七キ（実際には約 50 分 で平衡に達した。）を行ない，口過後収着に用いたのと 同様の混合溶液 $700 \mathrm{ml}$ により洗浄を行なった。一夜 $105^{\circ} \mathrm{C}$ にて乾燥し, キールダール法により窒素分析を行 なった。

\section{2 膨 潤 率}

前述のパルプより作られた紙を $1 \times 4 \mathrm{~cm}^{2}$ に切断し， 重量範囲が $0.2850 \pm 0.0050$ 以内のものを選びだして, 各種混合溶剤 $25 \mathrm{ml}$ に浸セキし, その重量増加量を測定 した。平衡に達するのに 2 週間要した。実験は 3 回繰り 返しその平均値より膨潤率を算出した。 


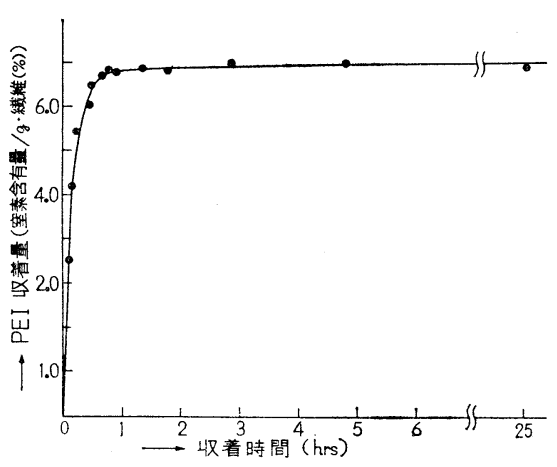

図-1 PEI の収着量と収着時間との関係 $(\mathrm{pH} 9.7$ に打ける収着, 洗浄は水 $700 \mathrm{ml}$ )

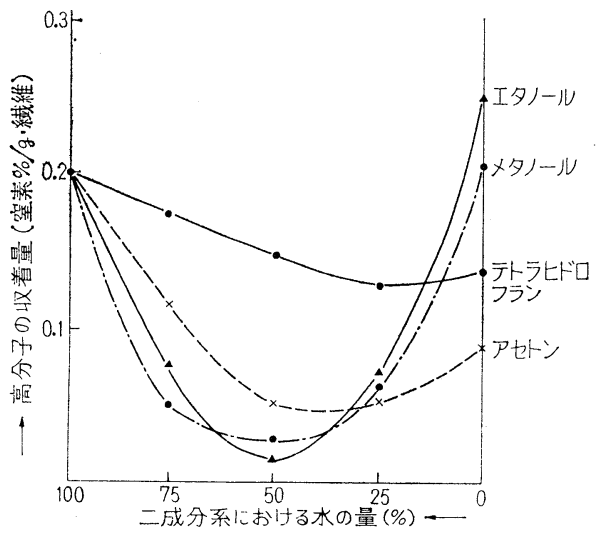

図-2 二成分系に持ける高分子収量着と水分との関係

\section{3 比粘度}

オストワルド粘度計を用い, 温度 $30^{\circ} \mathrm{C}$ の恒温槽中に てPEIの各種混合溶液の粘度を測定した。

\section{3. 結果と考察}

\section{1 水一有機溶媒混合系における収着}

図-2 の結果より, 溶媒比が同等の場合に, アルコ一 ル系溶媒に执いて最小の収着量を示した。テトラヒド口 フラン（以後 THF と略す）特よびアセトンではとれは ぞはっきりした最小值を示さず, アセトンの際, 最小值 はアセトン側に移行した。

有機溶媒中に特ける PEI の収着量ではエチルアルコ ール, メチルアルコールとも水溶媒に比べて高い值を示 した。他方，アセトン拈よび THF 中では水溶媒中に打 けるよりる低い収着量を示した。

以上の上らに, 水一アルコール系混合溶媒中では最小 収着量を示すことが認められた。それでは, 一方の溶媒 中にて収着させ, 次に他方の溶媒を用いて洗浄するなら ば同様に最小収着量を示すかどうか興味あるので，この
表-1 PEI 収着に対する洗浄溶剤の効果

\begin{tabular}{|c|c|c|}
\hline 収着に使用した溶剤 & 洗 浄 溶 剂 & $\begin{array}{c}\text { PEI 収着量 } \\
\text { (窒素\% } \% / g \text { 䋐維) }\end{array}$ \\
\hline 水 & 水 & 0.200 \\
\hline 水 & メタノール & 0.205 \\
\hline メタノール & メタノール & 0.210 \\
\hline メタノ $-ル$ & 水 & 0.194 \\
\hline メタノ一ルー水 & 水 & 0.024 \\
\hline メタノールー水 & メタノール & 0.028 \\
\hline メタノールー水 & メタノールー水 & 0.025 \\
\hline
\end{tabular}

点につき検討した。その結果, 表-1から, 水またはメ チルアルコール溶剤中で収着し, 次に水またはメチルア ルコールで洗浄した場合の収着量と, 水一メチルアルコ 一ル混合溶剂中で収着し，水，メチルアルコールまたは その混合溶剂で洗浄した場合の収着量を比較すると単独 溶剂中で収着した方が混合系より約 8 倍高い収着量を示 した。一方洗浄時の溶剤の違いによる収着量の差はそれ に比べるとわずかであった。

\section{2 膨潤率の影響}

この収着現象を解明する手段としては，まず纎維の膨 潤がどの程度吸着に影響を及ぼすかを調べ，次に粘度の 変化より高分子の広がり状態を検討した。な特膨潤率は 次の式に従って算出した。

$$
Q=\frac{1}{\phi_{2}}
$$

ここにQは膨潤比で，試料扔よび溶媒の密度を $\zeta_{1}, \zeta_{2}$, 膨潤前後の重量を $W, W^{\prime}$, 各溶媒の体積を $V_{1}, V_{2}$, その混液に括ける試料と溶媒の体積分率を $\phi_{1}, \phi_{2}$ とす るならば,

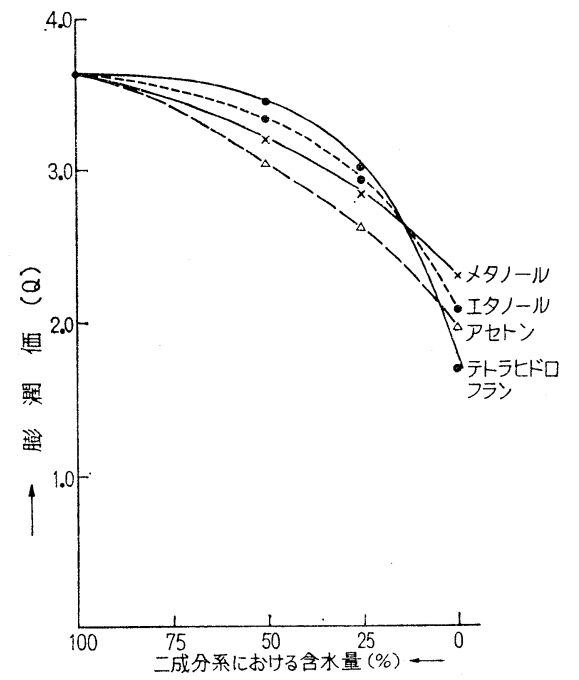

図-3 二成分系に括汀る膨潤価と含水量との関係 


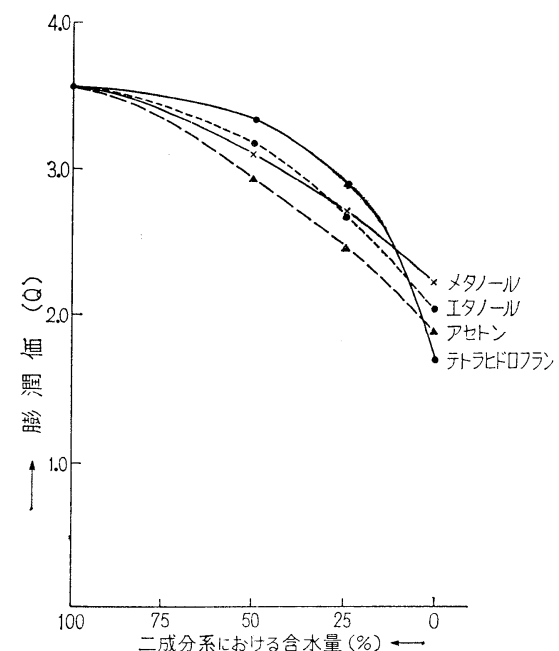

図-4 二成分系に括ける膨潤価と含水量との関係 (PEI 添加後)

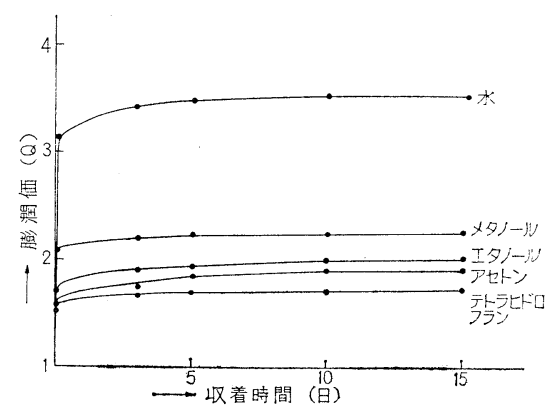

図-5 膨潤と収着時間との開係

$$
\begin{aligned}
\frac{\zeta_{1} \phi_{1}}{\zeta_{2} \phi_{2}} & =\left(\frac{1-\phi_{2}}{\phi_{2}}\right)\left(\frac{\zeta_{1}}{\zeta_{2}}\right)=\frac{W^{\prime}-W}{W} \\
Q & =1+\frac{\zeta_{2}}{\zeta_{1}}\left(\frac{W^{\prime}}{W}-1\right)
\end{aligned}
$$

その結果，まず膨潤率の測定値は図-3，4にみられる ように図-2 の収着現象をうまく説明できないが，乙か しながらこの図より PEI の存在は繊維の膨潤を少し増 加させることが認められた。また混合系に执いて有機溶 媒比率の増加は膨潤率を低下させることが認められた。 このことは水がもっともよくセルロースと相互作用をす るためと推定される。

Robertson 5 ${ }^{3)}$,4) は各種有機溶媒系に誩ける高分子の セルロースに対する収着を繊維の膨潤にも関係を持たせ ているが，使用した高分子は PEI のような高分子電解 質ではなかった。高分子電解質の場合には実験結果より 直接的な関係はないものと考えられる。

\section{3 高分子鎖の広がりの影響}

次に固有粘度の測定結果は，図-6 から明らかなよう

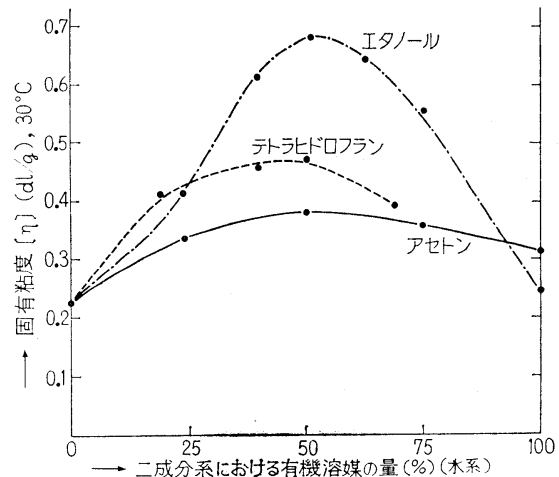

図-6 固有粘度と有機溶媒 $(\%)$ (水との二成分系) との関係

に，水または有機溶媒自体の場合にに低い值を示してい るが，一方，混合溶液中では高い值を示すことが認めら れた。すなわち，混合溶液中ではポリマー分子鎖が十分 に広がって拉り，繊維中の細孔(1),5) 中に浸透しにくいと 考えられる。すなわち, 系まり状の高分子鎖が細孔より も小さい場合には細孔中に収着されるが，大きい場合に は細孔内に入り込めないので収着されないと考えられ る。

特に PEI は直鎖状ポリマーでなく，むしろ三次元的 橋カケをした構造を持っているためにいっそう繊維の細

1. セルロースへの高分子の収着 (ストーンの模型)

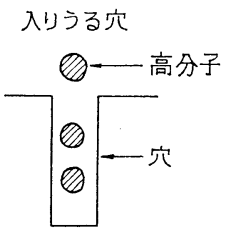

高分子の径よりも穴の 径が大きい。
入りえない穴

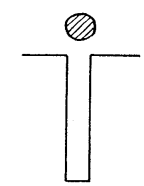

高分子の径よりも穴の 径の方が小さい。
2. びっくり箱効果

$\bigotimes$

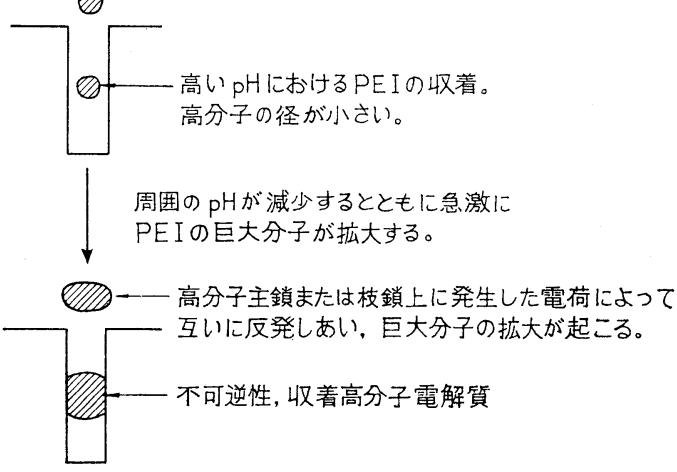

図-7 ストーンの模型とわれわれのビックリ箱効果 


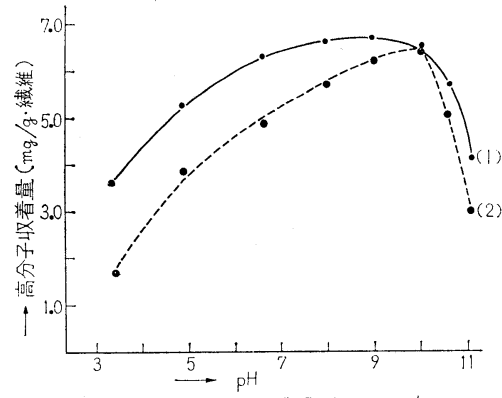

(1) 収着pHは変化するが洗浄 $\mathrm{pH}$ H 7で一定。

(2) 洗浄 $\mathrm{pH}$ は变化するが収着 $\mathrm{pH}$ H 9.7 で一定。

図-8セルローズへのPEIの収着に及ぼす洗浄 および収着 $\mathrm{pH}$ の影響

孔の大きさが収着量に影響を及ぼすものと考えられ る。

$$
\text { ポリマー中 }\left\{\begin{array}{l}
\text { 第一級アミン: } 25 \% \\
\text { 第二級アミン: } 50 \% \\
\text { 第三級アミン: } 25 \%
\end{array}\right.
$$

1. 水一溶媒

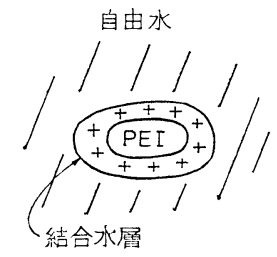

インン化による拡大分子

3. 有機溶剂

自由溶威:

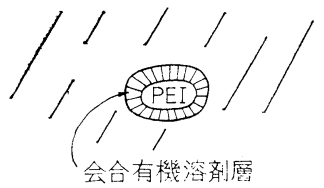

脱イオン化によるしぼられた分子

図-10 二成分系に扮ける二重層の仮説

10 以上では急激に低下することが認められた。この結 果も前述同様に説明できるものと考えられる。

\section{4. 全般的考察}

以上の研究結果から, 高分子電解質の水一有機 溶媒混 合系に和ける収着現象に特いては高分子鎖の広がり状態 が収着に大きく寄与していることが判明した。もちろん ベンゼンのような PEI に対して溶解性の小さい溶媒の 場合には，高分子は定性的に知られているように，その 系より逃避しょらとして固体表面に行くため非常に高い 収着量を示した（図-9 参照)。しかし，これは水-有機 溶媒混合系に拈将る収着とは異なるものと考えられる。

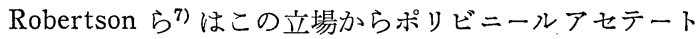
のセルロースに対する収着を論じている。しかし，PEI の収着現象は前報1),2) に和いて述べられたビックリ箱効 果により説明できるであろら。すなわち, 高分子電解質 の大きさは周囲の $\mathrm{pH}$ により変化し, 収着体の細孔より 小さいとさにはより多く浸透し, 逆の場合には高分子鎖 は細孔内に入り込めないため少ない収着量を示すと考光 られる。

高分子電解質の水-有機溶媒混合系では, 固有粘度の 上昇が認められたが，これは水と有機溶媒の相互作用が 高分子電解質の分子の広がりに大きく寄与していること を示している（図-6 参照)。Molyneux らの考えにより 一応図-10 のよらな状態により粘度上昇を伴らと推定さ れる ${ }^{9)}$ 。また井本ら ${ }^{8)}$ は高分子溶液の固有粘度 $[\eta]$ と固 体に対する平衡吸着量 $\left(A_{S}\right)$ との間に次のような関係を 得ている。 


$$
\begin{aligned}
& A_{S}=K /[\eta]^{\frac{2}{3}[\eta]} \\
& K: \text { 定数 } \\
& {[\eta]^{2 / 3}: \text { 高分子の広がりに関するパラメーター }}
\end{aligned}
$$
このことからも高分子の固体面に対する吸着量は高分 子鎖の広がりが大きければ減少し，小さければ増大する ことがわかる。

付記 本実験に助言をいただいた元関西ペイント中央 研究所長重名潔博士に深く感謝する。

$$
\text { 文献 }
$$

1) Allan, G., Akagane, K.. Neogi, A., and Reif, W., Proc. Tappi Paper Physics Seminar, (May 1969)
2) Allan, G., Akagane, K., Neogi, A., Reif, W., and Mattila, T., Nature, 225, 175 (1970)

3) Alince, B., Kuniak, L., and Robertson, A., $J$. Appl. Polym. Sci., 14, 1577 (1970)

4) Chan, F.S., Minhas, P.S., and Robertson, A., J. Colloid Interface Sci., 33, 586 (1970)

5) Stone, J., and Scallan, A., Cell. Chem. Tech., 2, 343 (1968)

6) Trout, P., Tappi, 34, 539 (1951)

7) Chan, F.S., and Robertson, A.A., J. Colloid Interface Sci., 33, 598 (1970)

8) Hara, K., and Imoto, T., Kolloid-Z.u.Z. Polymere, 237, 297 (1970)

9) Molyneux, P., and Frank, H. P., J.Am.Chem. Soc., 83, 3169 (1961).

\section{色 材 協 会 誌 Vol.44 No.12 (予告)}

報文

塗膜の顕徽鏡的研究（第 1 報）

塗色の演色評価に関する研究

大日本塗料(株) 道 野 鶴 松 他

テーマ資料 関西ペイント(株) 品 田登 他

スチンン系の含水合成木材の現状または海外事情・

湘南積水工業(株) 大 島 幹 義

ポリエステル系の含水合成木材 ..日本化薬(株) 箕 輪 輯 二

\section{一般 資 料}

塗料関係の DIN.

日本油脂(株) 太 田恵 三

文

献. 